Erratum

\title{
Erratum for Alveolar Type II Cells Escape Stress Failure Caused By Tonic Stretch Through Transient Focal Adhesion Disassembly
}

\author{
Xiao-Yang Liu ${ }^{1,2}$, Xiao-Fei Chen ${ }^{3}$, Yan-Hong Ren ${ }^{1,2}$, Qing-Yuan Zhan ${ }^{1,2}$, Chen Wang ${ }^{1,2} \bowtie$, Chun Yang $^{3} \bowtie$ \\ 1. Beijing Chao-Yang Hospital, Capital Medical University, China \\ 2. Beijing Institute of Respiratory Medicine, China \\ 3. Institute of Biomechanics and Medical Engineering, School of Aerospace, Tsinghua University, China \\ $\triangle$ Corresponding authors: Dr. Chen Wang, Beijing Chao-Yang Hospital, Capital Medical University, Beijing, 100020 (China). Dr. Chun Yang, IBME, School of \\ Aerospace, Tsinghua University, Beijing 100084 (China). Tel. +86 108513 2114; Fax +86 106506 0167; E-Mail: cyhbirm@mail.ccmu.edu.cn or \\ yangchun@tsinghua.edu.cn
}

(c) The author(s). This is an open access article distributed under the terms of the Creative Commons Attribution License (https://creativecommons.org/licenses/by/4.0/). See http://ivyspring.com/terms for full terms and conditions.

Published: 2020.06.11

Corrected article: Int J Biol Sci 201 1; 7(5):588-599. doi:10.7150/ijbs.7.588.

In our paper [1], the second panel of Figure 1c was mis-pasted. Fig. 1c should be corrected as follows.



AnnexinV binding

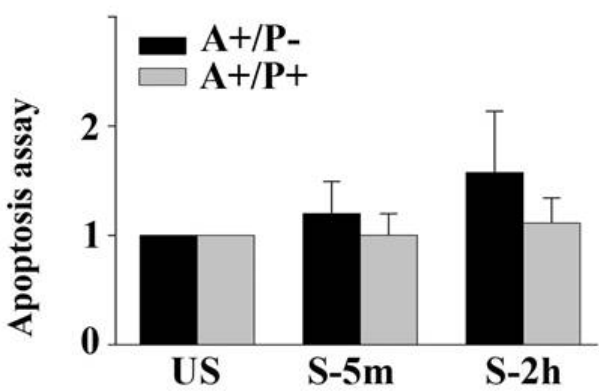

Figure 1. (A) Tonic stretch-induced ATII cell death over time ( $1 \mathrm{~min}, 5 \mathrm{~min}, 2 \mathrm{~h}$, and $4 \mathrm{~h}$ ). Cytoplasm of viable cells was stained with calcein-AM (green), and nuclei of nonviable cells were stained with ethidium homodimer-1 (red). Bar $=200 \mu \mathrm{m}$. (B) Statistical analysis of stretch-induced cell death over time, the cell death rate did not increase after 5 min. Values were means $\pm S D(n=8)$. $* P<0.001$ vs. unstretched cells (US); ${ }^{* * P}<0.001$ vs. S- $1 \mathrm{~m}$. (C) Cells were stained with annexin $V$ and PI, and analyzed by flow cytometry. AnnexinV-positive/PI-negative (lower right quadrant) represented the early apoptosis, annexinV-positive/PI-positive (upper right quadrant) represented the late apoptosis/necrosis. Apoptosis rate was not sig-nificantly different between US and stretch group ( $\mathrm{S}-5 \mathrm{~m}$ and $\mathrm{S}-2 \mathrm{~h}$ ). Values were means $\pm \mathrm{SD}$ ( $\mathrm{n}=8$ ). (D) Tonic stretch-induced cell morphological remodeling was detected by SEM. During the stretch, cells experienced expansion $(1 \mathrm{~min})$, contraction $(5 \mathrm{~min})$, and reexpansion $(2 \mathrm{~h})$. Bar $=20 \mu \mathrm{m}$. $(\mathrm{E}) \mathrm{Stretch}$ induced cell morphological remodeling. Im-munofluorescence of representative cells at the time indicated for actin (red), unclear (blue), and FA marker VIN (green). Bar $=10 \mu \mathrm{m}$. (F) Quantitative analysis of FAs fluorescence intensity during the stretch showed that cells experienced rapid FAs disassembly and sequential reassembly. * $\mathrm{P}<0.01$ vs. US; ** $\mathrm{P}$ $<0.01$ vs. S-5m. Values were means \pm SD $(n>60)$ 
All the authors have read the erratum and agree with the correction.

\section{References}

[1] Liu XY, Chen XF, Ren YH, Zhan QY, Wang C, Yang C. Alveolar Type II Cells Escape Stress Failure Caused by Tonic Stretch through Transient Focal Adhesion Disassembly. Int J Biol Sci 2011; 7(5):588-599. 